\title{
Biochemical and Nutritional Importance of Winged Bean (Psophocarpus tetragonolobus (L.)) on Wistar Rats
}

\author{
Adewale Michael Esan, ${ }^{1, *}$ Charles Ojo Olaiya', Samson Tolulope Adedire ${ }^{1}$, Folusho Eunice \\ Bamigboye $^{1}$, Kehinde Olugboyega Soetan ${ }^{2}$
}

${ }^{1}$ Department of Biochemistry, Faculty of Basic Medical Sciences, University of Ibadan, Ibadan, Oyo State, Nigeria.

${ }^{2}$ Department of Veterinary Physiology, Biochemistry and Pharmacology, University of Ibadan, Ibadan, Oyo State, Nigeria.

How to cite this paper: Adewale Michael Esan, Charles Ojo Olaiya, Samson Tolulope Adedire, Folusho Eunice Bamigboye, Kehinde Olugboyega Soetan. (2020) Biochemical and Nutritional Importance of Winged Bean (Psophocarpus tetragonolobus (L.)) on Wistar Rats. International Journal of the Science of Food and Agriculture, 4(2), 174-182.

DOI: 10.26855/ijfsa.2020.06.009

Received: April 13, 2020

Accepted: May 12, 2020

Published: May 27, 2020

*Corresponding author: Adewale Michael Esan, Department of Biochemistry, Faculty of Basic Medical Sciences, University of Ibadan, Ibadan, Oyo State, Nigeria.

Email: adexphotocopa@yahoo.com

\begin{abstract}
Recently, food-security and sustainability have become a serious global concern, leading to malnutrition in the developing countries. Winged bean is an underutilized and neglected legume indigenous to Africa. In this study, we evaluated in vitro and in vivo nutritional properties of processed and unprocessed winged bean. Furthermore, we investigated impact of dietary intake of winged bean diets on biochemical factors pertaining to body weight gain, lipid profiles, antioxidant enzymes, and liver and kidney functions of experimental rats over a 6 -week study period. Twenty-one rats were divided into three groups $(n=7)$, and fed with three diets (normal pellet diet, pure processed winged bean alone, and $50 \% \mathrm{w} / \mathrm{w}$ processed winged bean). Our results show higher nitrogen free extract in the processed winged bean than the unprocessed one. A significant difference $(P>0.05)$ in moisture content was observed between the unprocessed and processed winged bean. The levels of phytate and oxalate in the processed winged bean were significantly $(P<0.05)$ reduced. However, saponin and tannins levels were increased in the processed winged bean. The calcium, phosphorus, magnesium, sodium, and potassium contents observed in the processed winged bean were higher than the unprocessed winged bean. The higher weight gain was observed in the rats fed with 100\% winged bean as compared to the other groups. Lipid profiles analysis revealed decreased cholesterol and triglycerides levels with an increase level of HDL in the rats fed on $100 \%$ winged bean as well as $50 \% \mathrm{w} / \mathrm{w}$ winged bean diet as compared to the control group. The liver and colon catalase and superoxide dismutase activities were significantly $(P<0.05)$ increased in the processed winged bean diet. It can therefore be concluded that the consumption of processed winged bean could reduce the menace of malnutrition, and also use as a substitute for soybean.
\end{abstract}

\section{Keywords}

Winged bean, Minerals, Anti-nutritional factors, Antioxidant enzymes, Wistar rats

\section{Introduction}

Food insecurity is a major challenge in most African countries, and as such, malnutrition rate is increasing geometrically. It is estimated that about 800 million people will be malnourished in 10 years to come. The menace of food insecurity is a serious global concern. Many people in developing countries suffer from protein malnutrition 
which has a negative impact both on health and economic [1]. Legumes are important source of oils and proteins [2]. Legume belong to the family of Fabaceae and has been recognized to be the second most valuable plant protein source for human and animal nutrition [3]. Some legumes are commercially used as staple food crops in West Africa like cowpea, soybean, etc., while some are underutilized outside their indigenous areas such as African yam bean, winged bean etc. [4]. The underutilization of these legumes can be as a result of poor information on food uses or tedious effect of cooking them. Winged bean is an abandoned crop. However, it has some nutritional value relatives to soybean [5]. The nutritional quality of winged bean seeds is creating unique commercial and research interest among leguminous plants. All parts (flowers, green pod, tubers and leaves) of winged bean are suitable for consumption [6]. This is a domesticated plant species that have been used for ages past for their fiber, oil, high dietary protein as a result of their amino acid content, medicinal properties or low levels of anti-nutritional factors [5], but over time the importance have been reduced due to supply and use constraints. Research on the winged bean seeds nutritional composition could help to decipher how winged bean can serve as a substitute for soybean with similar features [7]. To avert food insecurity and poverty worldwide, intensive research studies on the underutilized crops is mandatory. Tropical and Sub-tropical regions in Africa favour the growth of many underutilized legumes, but the major constraint on these legumes is the inadequate research knowledge on their nutritional compositions, and how to utilize them as food to improve nutritional status. In this study, both in vitro and in vivo analyses of biochemical effects of processed winged bean seeds were evaluated.

\section{Materials and Methods}

\subsection{Plant Material}

Winged bean seeds sample were acquired from International Institute of Tropical Agriculture (IITA) Ibadan, air-dried ground into powder, and one part of the powder was for the determination of proximate analysis, minerals content, and anti-nutritional factors and the other part was pelletized. The pellets were processed by oven drying at $60^{\circ} \mathrm{C}$ for four hours.

\subsection{Animals}

Protocols and methods used to maintain rats in this study were approved by the University of Ibadan's Animal Use and Care Committee. Twenty-one male albino rats (6-weeks old) were obtained from the Veterinary Animal House at the University of Ibadan. The rats were acclimatized for a week. After the acclimation period, the rats were randomly divided into three groups $(\mathrm{n}=7)$ per metabolic cage with access to food, water ad libitum, and under optimal vivarium conditions (12-h/12-h light-dark cycle, $24 \pm 1^{\circ} \mathrm{C}$ and $40-50 \%$ relative humidity). Two experimental diets were used (50\% processed winged bean and 50\% normal pellet diet; and 100\% processed winged bean). The grouping is as follows:

Group A (Control): rats received rat normal pellet diet alone.

Group B (WB only): rats received pure processed winged bean alone.

Group C (WB+ NPD): rats received 50\% processed winged bean and 50\% normal pellet diet.

The abbreviations denote: $\mathrm{WB}=$ winged bean only and $\mathrm{WB}+\mathrm{NPD}=$ winged bean and Normal Pellet Diet.

On the sixth week, twenty-four hours after the last treatment, blood was collected into non-heparinized tubes by ocular puncture using capillary tubes. After which the animals were sacrificed by cervical dislocation and their kidneys, livers and colon were then carefully harvested. Then, the serum was centrifuged at $4,000 \mathrm{~g}$ for $10 \mathrm{~min}$ using a cold centrifuge. Tissues for biochemical assays were placed in $1.15 \%$ potassium chloride (KCI) ice-cold solution, blotted dry and weighed. Then the tissues were homogenized in ice-cold phosphate buffer $(\mathrm{pH} 7.4)$ using a 1:4 tissue weight to buffer ratio. The resulting homogenates were centrifuged for $10 \mathrm{~min}$ at $12,000 \mathrm{rpm}$ using a cold centrifuge at $4^{\circ} \mathrm{C}$.

\subsection{Proximate Composition of the Processed and Unprocessed Winged Bean}

\subsubsection{Determination of the moisture content}

The moisture content of dried winged bean powder was estimated by using an oven at $80^{\circ} \mathrm{C}$ for 24 hrs. The result is expressed as a percentage.

\subsubsection{Determination of the crude protein, crude lipid, and crude fibre contents}

Crude protein of dried winged bean powder was estimated by Kjeldahl method using the procedure of Gupta [8]. Crude fat of dried winged bean powder was determined by using Soxhlet apparatus method according to the AOAC [9]. Crude fibre of dried winged bean powder was estimated according to the method of Chopra and Kanwar [10].

\subsubsection{Determination of ash content}


The methods of Association of Official Analytical Chemists [9] was used to determine the ash content of dried winged bean powder. About $4 \mathrm{~g}$ of dried bean powder sample was dried and weighed and put into pre-weighed silica crucible. The incineration was done at $550-600^{\circ} \mathrm{C}$ in a muffle furnace for $3 \mathrm{hrs}$. Then, the sample was removed from muffle furnace after incineration with the help of a tong and cooled in a desiccator and weighed.

Therefore, the ash content was calculated by using the following formula.

$$
\% \text { Weight of ash }=Y-\frac{X}{W} \times 100
$$

Where, $\mathrm{X}$ is the weight of empty silica crucible,

$\mathrm{Y}$ is the weight of crucible + Ash,

$\mathrm{W}$ is the weight of dry sample.

\subsubsection{Determination of nitrogen free extract (NFE)}

The difference in moisture, crude protein, fat, and ash content data was used to estimate the nitrogen free extract (NFE) in the dried winged bean powder. The nitrogen free extract was calculated by using the formula.

$$
\text { NFE }=\text { Moisture content }- \text { crude protein }- \text { crude fat }- \text { crude ash content } \text {. }
$$

\subsubsection{Determination of crude fat}

Crude fat was determined according to the AOAC [11] method. About $3 \mathrm{~g}$ of dried winged bean powder sample was taken into an extraction thimble inside the soxhlet extraction unit. A $50 \mathrm{~mL}$ petroleum ether (b.p. $60-80^{\circ} \mathrm{C}$ ) was added into a round bottom flask and connected to the condenser. Condensation rate was set to 2-3 drops by adjusting heating rate, and the process was continued for consecutive 8 hrs. After the extraction process, the thimble and ether were removed. The flask was dried at high temperature for half an hour in an oven and cooled in a desiccator and then weighed. Then, the $\%$ crude fat was determined by using the formula.

$$
\% \text { Crude fat }=\frac{\text { Weight of fat }}{\text { Weight of dry sample }} \times 100
$$

\subsection{Antinutrient composition of the processed and unprocessed winged bean}

\subsubsection{Determination of tannin content}

The tannin content of processed and unprocessed winged bean was estimated by using the method described by Adegunwa et al. [12]. A $10 \mathrm{~mL}$ of $70 \%$ aqueous acetone was used to extract $0.5 \mathrm{mg}$ of defatted winged bean powder for $2 \mathrm{hrs}$ under water bath at $30^{\circ} \mathrm{C}$. Centrifugation of the extract was done for $20 \mathrm{~min}$ at $1,000 \mathrm{rpm}$. Then to $0.05 \mathrm{~mL}$ of the supernatant, $0.5 \mathrm{~mL}$ of a Folin-Ciocalteu reagent was added. A standard tannic acid was used. The absorbance was read at $725 \mathrm{~nm}$ against distilled water by using a UV/Visible spectrophotometer.

\subsubsection{Determination of saponin content}

The total saponin content of processed and unprocessed winged bean powder wad determined using the procedure described by Makker and Becker [13]. A. $0.5 \mathrm{mg}$ of defatted winged bean powder was extracted with petroleum ether $(10 \mathrm{~mL})$ with intermittent shaking for about 4 hours. Then, $5 \mathrm{~mL}$ of aqueous methanol was used to extract the residue. The supernatant total saponin content was determined at $544 \mathrm{~nm}$ by using a UV/Visible spectrophotometer.

\subsubsection{Determination of oxalate content}

The method of Leyva et al. [14] was used to estimate the tannin content of processed and unprocessed winged bean. A. $0.5 \mathrm{mg}$ of defatted winged bean powder was extracted with $70 \%$ aqueous acetone $(10 \mathrm{~mL})$ for 2 hrs under water bath at $30^{\circ} \mathrm{C}$. The extract was centrifuged for $20 \mathrm{~min}$. at $12,000 \mathrm{rpm}$. A $0.05 \mathrm{~mL}$ of the supernatant was taken for the oxalate content determination. Oxalic acid was applied as the standard. The total content of oxalate was determined at $440 \mathrm{~nm}$ by using a UV/Visible spectrophotometer.

\subsubsection{Determination of phytate content}

The total phytate content of winged bean powder wad determined using the procedure described by Gao et al. [15]. A. $0.5 \mathrm{mg}$ of defatted winged bean powder was extracted with petroleum ether $(10 \mathrm{~mL})$ and vortex for 4 hours. A $10 \mathrm{~mL}$ of $24 \% \mathrm{HCl}$ was used to extract the residue with an intermittent shaking for $6 \mathrm{hrs}$. The supernatant total phytate content was determined at $500 \mathrm{~nm}$ by using a UV/Visible spectrophotometer.

\subsection{Protocol for minerals content analysis in the processed and unprocessed winged bean}

A muffle furnace of high temperature $\left(400^{\circ} \mathrm{C}\right)$ was used for the combustion of $5 \mathrm{~g}$ of winged bean powder in a crucible. The winged bean was heated until the smoke stopped. The content of the crucible was cooled in a desiccator at $27^{\circ} \mathrm{C}$. The concentrated sulphuric acid was used to soak the defatted ash on the heating mantle. Then, the constant weight of the ash residue was obtained when heated at $600^{\circ} \mathrm{C}$. The mineral elements in $1 \mathrm{~g}$ of the ash was obtained by dissolving it in $100 \mathrm{~mL}$ of $5 \% \mathrm{HCl}$ [9]. 
2.5.1. Cationic ions contents estimation in the processed and unprocessed winged bean

According to AOAC [9], the atomic absorption spectrophotometer flame (BULKS SCIENTIFIC ${ }^{\circledR}$ model AA 240) was used to estimate cationic concentrations.

\subsubsection{Sodium ( $\mathrm{Na}$ ) ion content estimation in the processed and unprocessed winged bean}

Flame Photometry was used to determine the $\mathrm{Na}^{+}$concentration by following the method of AOAC [9]

\subsubsection{Processed and unprocessed winged bean phosphorus $(P)$ content estimation}

Spectrophotometry method according to the procedure of AOAC [9] was used to determine phosphorus concentration.

\subsection{Determination of body weight of the experimental rats}

The body weights of the experimental animals were estimated with the used of weighing balance by subtracting initial body weight from the final body weight.

\subsection{Biochemical assays}

The supernatant collected from the centrifugation of the liver, kidney and colon tissues homogenate were then used for biochemical assays. All biochemical assays were analyzed using UV/Visible spectrophotometer.

\subsubsection{Catalase activity determination in the experimental rats}

The method proposed by Khan [16] was used to estimate catalase activities. Briefly, the reacting medium consists of $2.5 \mathrm{~mL}$ of $50 \mathrm{mM}$ phosphate buffer $(\mathrm{pH} 5.0), 5.9 \mathrm{mM} \mathrm{H}_{2} \mathrm{O}_{2}(0.4 \mathrm{~mL})$, and $0.1 \mathrm{~mL}$ of the enzyme extract. The changes in the disappearance of hydrogen peroxide after one minute was measured at $240 \mathrm{~nm}$ using UV/Visible spectrophotometer.

\subsubsection{Superoxide dismutase (SOD) activity determination in the experimental rats}

The SOD assay kit (Randox Lab., Ltd., UK) was used to determine the SOD activities, by following the protocol of the manufacturer.

\subsubsection{Glutathione peroxidase (GPx) activity determination in the experimental rats}

The GPx assay kit (Randox Lab., Ltd., UK) was used to determine the GPx activities, by following the protocol of the manufacturer.

\subsection{Determination of kidney and liver function tests in the experimental rats}

The activity of Aspartate aminotransferase (AST), Alkaline phosphatase (ALP) and Alanine aminotransferase (ALT), the creatinine and urea levels in the serum were determined by using kits (Randox Lab., Ltd., UK) based on the protocol of the manufacturer.

\subsection{Determination of lipid profile assay}

Lipid profile of the experimental rats was determined through random selection from each treatment. The method described by Young [17] was used to determine the lipid profile.

\subsection{Statistical analysis}

Seven rats were used in each group in order to have sufficient statistical power to detect significant difference at $\mathrm{P}<0.05$ and a power of $80 \%$ in values from biological samples. Data were analysed using One-way Analysis of Variance (ANOVA) followed by the application of the Tukey-Kramer's multiple to determine statistically differences among the groups. For proximate analysis, three replicates were used for the analysis. All results are presented as mean \pm standard deviation (SD).

\section{Results}

\subsection{Processed and unprocessed winged bean proximate composition}

Figure 1 shows significant $(P<0.05)$ difference of the nitrogen free extract content in the processed winged bean as compared to the unprocessed one. Also, the crude protein, crude lipid, crude fibre, and ash contents of processed winged bean were higher than the unprocessed winged bean. However, moisture content of processed and unprocessed winged bean showed no significant difference.

\subsection{Anti-nutrient composition of the processed and unprocessed winged bean}

The phytate and oxalate anti-nutrient contents of unprocessed winged bean was observed to be significantly higher than the processed one. However, tannins and saponin contents were higher in the processed than the unprocessed winged bean (Figure 2). 


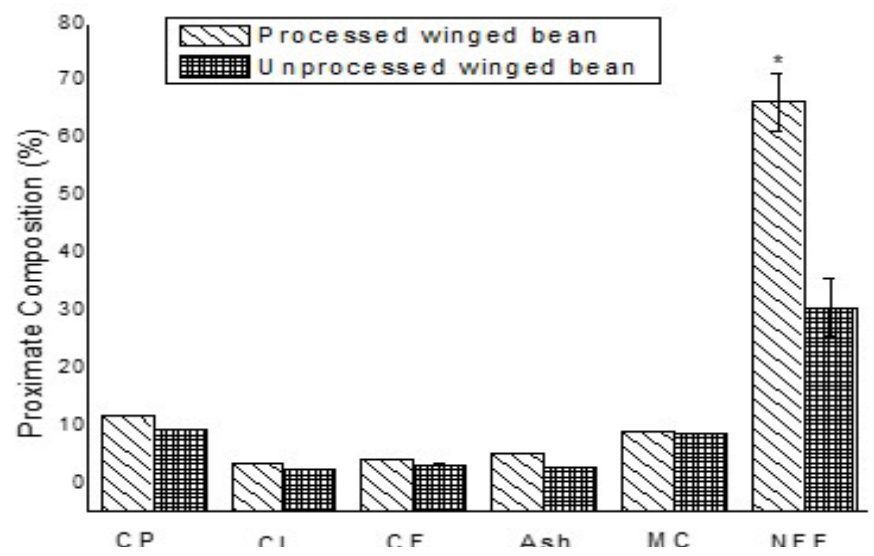

Figure 1. The processed and unprocessed winged bean proximate composition.

$\mathrm{CP}=$ crude protein; $\mathrm{CL}=$ crude lipid; $\mathrm{CF}=$ crude fibre; $\mathrm{MC}=$ moisture content; $\mathrm{NFE}=$ nitrogen free extract. Values are mean \pm SD $(\mathrm{n}=3)$. *Significant $(P<0.05)$ difference from unprocessed winged bean.

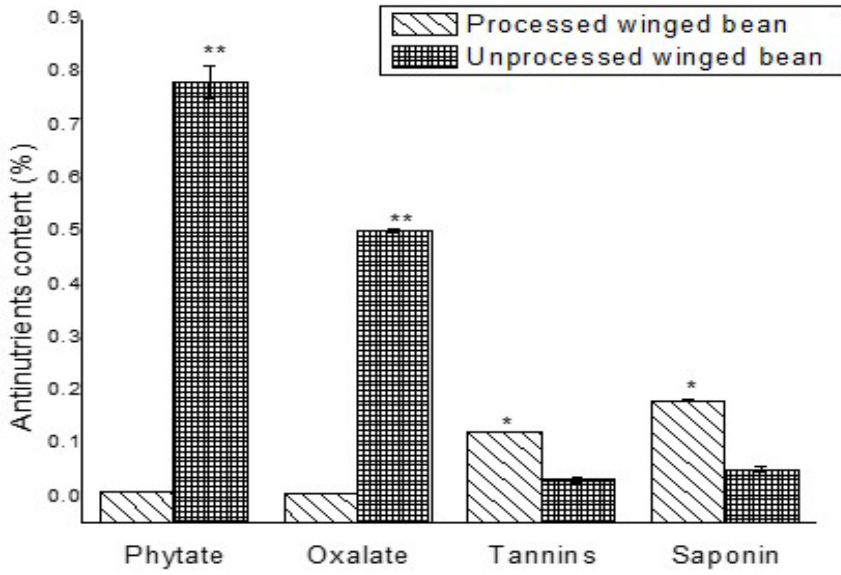

Figure 2. Concentration of antinutrient factors in processed and unprocessed winged bean.

Values are mean $\pm \operatorname{SD}(n=3){ }^{* *, *}$ Significant $(P<0.05)$ difference from processed and unprocessed winged bean respectively.

\subsection{Minerals content analysis in the processed and unprocessed winged bean}

Figure3 shows significant $(P<0.05)$ increase in the percentage levels of calcium, magnesium, sodium, and potassium in the processed winged bean than the unprocessed winged bean. However, phosphorous contentin both processed and unprocessed winged bean showed no significant $(P>0.05)$ difference.

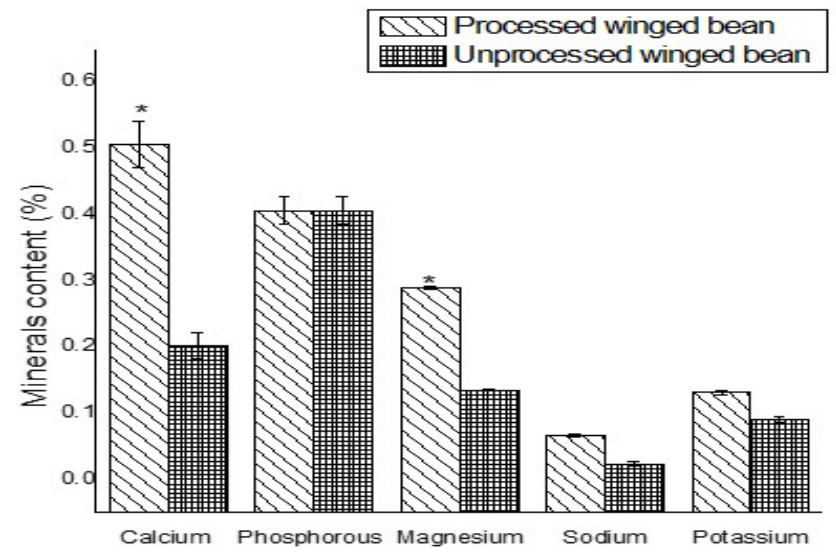

Figure 3. The Processed and unprocessed winged bean minerals content.

Values are mean $\pm \mathrm{SD}(\mathrm{n}=3)$. *Significant $(P<0.05)$ difference from unprocessed winged bean. 


\subsection{Effect of processed winged bean on the experimental rats' body weight}

Table 1 shows that the diets (processed winged bean) fed to the experimental rats for a period of 45 days resulted in a statistically significant increase in the body weight of group of rats fed with $100 \%$ processed winged bean and the group fed with 50\% processed winged bean with 50\% normal pellet diet respectively relatives to the control group.

Table 1. Effects of processed winged bean on body weight of the experimental rats

\begin{tabular}{cccc}
\hline & Before treatment(g) & After treatment(g) & Weight gain(g) \\
\hline Control & $155.77 \pm 27.48$ & $180.00 \pm 11.87$ & $24.23 \pm 16.98$ \\
WB diet & $155.60 \pm 14.14$ & $188.60 \pm 24.47$ & $33.00 \pm 10.32$ \\
WB+ NPD diet & $155.63 \pm 34.97$ & $183.43 \pm 31.00$ & $27.80 \pm 12.08$ \\
\hline
\end{tabular}

Data are mean $\pm \mathrm{SD}, \mathrm{n}=3$.

WB diet $=100 \%$ winged bean diet; WB + NPD diet $=50 \%$ winged bean $+50 \%$ normal diet.

\subsection{Effect of processed winged bean on the activity of antioxidant enzymes in the experimental rats}

Figure 4 (a, b) showed the activity of enzymes in the liver, kidney, and colon of the experimental rats fed with processed winged bean. The result revealed an increase activity of the liver and colon antioxidant enzymes in the group fed with $100 \%$ processed winged bean and the group fed with $50 \% \mathrm{w} / \mathrm{w}$ processed winged bean respectively relatives to the normal control group.
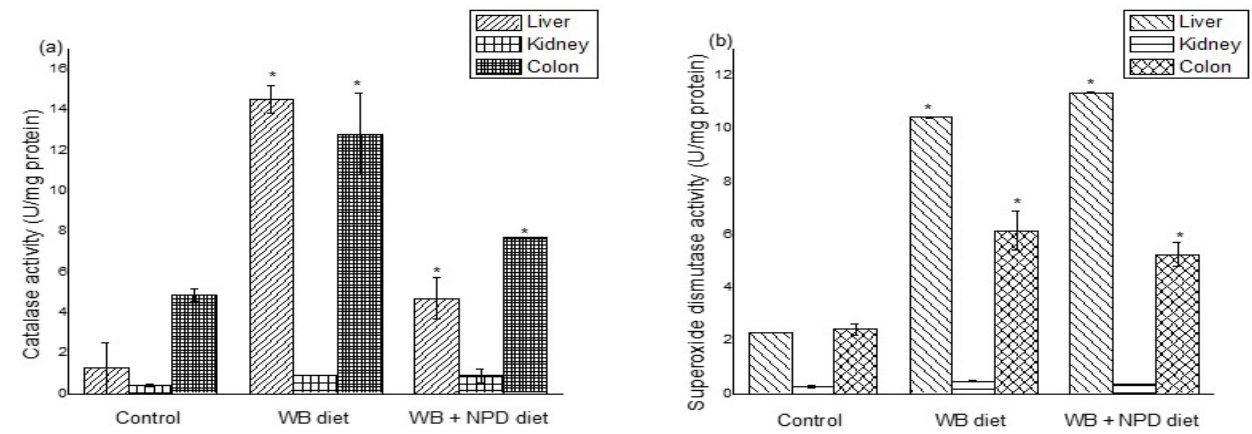

Figure 4(a, b). Effect of processed winged bean on the liver, kidney and colon antioxidant enzymes of the experimental rats.

Values are mean \pm SD $(n=3)$. ${ }^{*}$ Significant $(P<0.05)$ difference from the control groups.
WB diet $=100 \%$ winged bean diet; WB + NPD diet $=50 \%$ winged bean $+50 \%$ normal diet.

\subsection{Effect of processed winged bean on the lipid profile in the experimental rats}

In Figure 5, significant $(P<0.05)$ reduction of cholesterol and triglycerides levels were observed in the experimental rats group fed with $100 \%$ processed winged bean and the group fed with $50 \% \mathrm{w} / \mathrm{w}$ processed winged bean diet respectively relatives to the normal control group. However, HDL level was observed to be increased in the group fed with $100 \%$ processed winged bean and the group fed with $50 \% \mathrm{w} / \mathrm{w}$ processed winged bean diet respectively relatives to the normal control group.

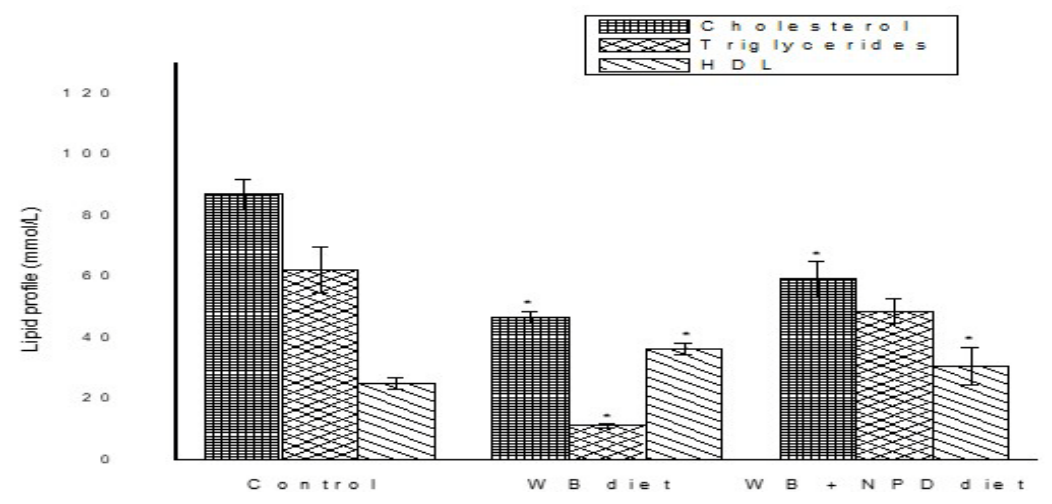

Figure 5. Effect of processed winged bean on the lipid profile of the experimental rats.

Values are mean $\pm \mathrm{SD}(\mathrm{n}=3)$. "Significant $(P<0.05)$ difference from the control groups.

WB diet $=100 \%$ winged bean diet; WB + NPD diet $=50 \%$ winged bean $+50 \%$ normal diet. 


\subsection{Effect of processed winged bean on kidney and liver function tests in the experimental rats}

Table 2 shows no significant increase in the urea and creatinine levels in the group fed with $100 \%$ processed winged bean and $50 \% \mathrm{w} / \mathrm{w}$ processed winged bean diet. However, a significant increase in the urea level was observed in the group fed with $50 \% \mathrm{w} / \mathrm{w}$ processed winged bean diet when compared with the normal control and $100 \%$ processed winged bean fed groups. In Table 3, no significant difference in the activity of ALP and ALT was observed in the group fed with $100 \%$ processed winged bean and $50 \% \mathrm{w} / \mathrm{w}$ processed winged bean diet respectively. However, a significant reduction in aspartate amino transferase (AST) activities was observed in rats fed with $100 \%$ processed winged bean diet and in the group fed with winged bean $50 \% \mathrm{w} / \mathrm{w}$ diet when compared to the control group.

Table 2. Effects of processed winged bean on kidney function of the experimental rats

\begin{tabular}{ccc}
\hline & UREA (mg/dL) & CREATININE (mg/dL) \\
\hline Control & $18.08 \pm 1.64$ & $0.40 \pm 0.16$ \\
WB diet & $18.45 \pm 1.00$ & $0.93 \pm 0.08$ \\
WB+NDP diet & $24.72 \pm 7.34^{* *}$ & $0.46 \pm 0.07$ \\
\hline
\end{tabular}

Data are mean $\pm \mathrm{SD}, \mathrm{n}=3$.

${ }^{* *}$ Significantly $(p<0.05)$ different from Winged bean diet fed rats.

$\mathrm{WB}$ diet $=100 \%$ winged bean diet; $\mathrm{WB}+\mathrm{NPD}$ diet $=50 \%$ winged bean $+50 \%$ normal diet.

Table 3. Effects of processed winged bean on liver function of the experimental rats

\begin{tabular}{cccc}
\hline & ALT (U/ml) & AST (U/ml) & ALP (U/l) \\
\hline Control & $30.18 \pm 7.45$ & $5.26 \pm 3.00$ & $46.78 \pm 0.61$ \\
WB diet & $29.81 \pm 1.09$ & $2.30 \pm 0.40^{*}$ & $46.63 \pm 1.35$ \\
WB+ NPD diet & $30.7 \pm 11.26$ & $7.20 \pm 5.05^{* *}$ & $47.2 \pm 3.50$ \\
\hline
\end{tabular}

Data are mean $\pm \mathrm{SD}, \mathrm{n}=3$.

${ }^{*}$ Significantly $(p<0.05)$ different from control, $p<0.05$.

${ }^{* *}$ Significantly $(p<0.05)$ different from Winged bean diet fed rats.

WB diet $=100 \%$ winged bean diet; WB + NPD diet $=50 \%$ winged bean $+50 \%$ normal diet.

ALT: Alanine amino transferase, AST: Aspartate amino transaminase, ALP: Alkaline phosphatase.

\section{Discussion}

In developing countries, the menace of protein-energy malnutrition is a major concern. Legumes are essential foods; they possess an essential amino acid which is often lacking in cereals. Supplementation of cereals with legume gives a balance of amino acid. Leguminous foods play an important role in averting the protein-energy malnutrition problem in the developing countries. In this study, the nitrogen-free extract (NFE) for the unprocessed winged bean was found lower than that of processed winged bean. This result was in tandem with previous report of Vadivel and Janardhanan [18] on Cassia floribunda Cav. The moisture contents of both unprocessed and processed winged bean fall within $0-13 \%$ as recommended. Similar report was observed by James [19]. The low moisture content suggests that the winged bean seeds have more shelf life. Antinutritional factors prevent bioavailability of the nutrients in the seeds of winged bean by forming a complex with proteins and minerals. However, all these factors may be denatured by processing using heat methods. In this current study, the levels of both phytate and oxalate in the processed winged bean were significantly $(P<0.05)$ reduced, which suggest that heat reduced both phytate and oxalate inhibitor activities. This may possibly due to the denaturation of phytate and oxalate inhibitors by high temperature. Pugalenthi et al. [20] reported similar observation. The levels of saponin and tannins were increased in the processed winged bean than the unprocessed winged bean. This result suggests that saponin and tannins confer antioxidant potential to the seed of winged bean. The contents of calcium, phosphorus, magnesium, sodium, and potassium observed in the processed winged bean were higher than the unprocessed winged bean. This suggests that heat releases mineral elements from the seeds, and thus ensure their bioavailability for the normal life processes.

Winged bean supplement had a significant effect on rats' weight. Rats fed with $100 \%$ winged bean had the highest weight gain as compared to those that fed on $50 \% \mathrm{w} / \mathrm{w}$ winged bean diet and control group respectively. This shows that the winged bean helps in building structural proteins. The rats that fed on $100 \%$ winged bean as well as $50 \% \mathrm{w} / \mathrm{w}$ winged bean diet showed decreased cholesterol and triglycerides levels with increase HDL relatives to the normal control group. This result suggests that winged bean is an important feed that reduces the risk of coronary heart diseases (CHDs). Marette and Picard-Deland [21] reported similar observation in yogurt supplementation of high fat diet. Processed winged bean diet in this study showed an increase activity of the catalase and superoxide dismutase in the 
liver and colon of the experimental rats. Wang et al. [22] reported the same observation in the experimental birds. Biochemical data revealed that liver functions markers were not significantly changed in the rats fed with $100 \%$ winged bean and winged bean $50 \% \mathrm{w} / \mathrm{w}$ diets relatives to the normal control group. However, a significant reduction in aspartate amino transferase (AST) activities in rat fed with $100 \%$ winged bean when compared to the control group and the group fed on winged bean $50 \% \mathrm{w} / \mathrm{w}$ diet. Similar report was observed in the study of Najafzadeh et al. [23]. No significant changes observed in the renal function except in the group fed on winged bean $50 \% \mathrm{w} / \mathrm{w}$ diet which showed an increase in the level urea when compared with the other groups. A reduction in creatinine level serves as a signal for clearance of creatinine and related to the expression of gene for ammonium elimination.

\section{Conclusion}

In conclusion, our findings revealed variation in the nutritional and anti-nutritional values of processed winged bean. The nitrogen free extract (NFE) in the processed winged bean was on the high side, and it can compare well with that of other legumes, and it could be used as other legume substitute in the meal for protein enrichment. The antinutritional composition was observed to be low with exception of saponin and tannins which serve as nutraceuticals. This study shows that the processed winged bean flour could be a good source of food supplement. Also, our study revealed that the processed winged bean had no negative effects either on liver or kidney functions. The processed winged bean supplementation had a significant effect on rats' weight. Therefore, processed winged bean may be beneficial to those that consume it, as it improves the level of high density lipoprotein, as well as antioxidant enzymes activity of the experimental rats. Therefore, with regards to the nutrient availability, low antinutritional content, and the level of mineral elements after processing. Further research work should be carried out on the sensory quality and the economic implications of consuming the seed.

\section{Funding}

This work was not funded by any funding agent.

\section{Acknowledgements}

We express our heartfelt gratitude to the International Institute of Tropical Agriculture (IITA) Nigeria for voluntarily provision of the winged bean seeds. More also, we are thankful to the Department of Veterinary Medicine Physiology and Biochemistry for the provision of the metabolic cage used.

\section{Conflict of Interests}

We all declare no conflict of interest in whatsoever manner.

\section{References}

[1] Semba, R. D., Shardell, M., Sakr Ashour, F. A., Moaddel, R., Teran, I., Maleta, K. M. et al. (2016). Child stunting is associated with low circulating essential amino acids. EBioMedicine; 6: 246-252.

[2] Lim, T. K. (2012). Edible Medicinal and Non-Medicinal Plants, vol. 1, Springer, Berlin, Germany.

[3] Wan Mohtar, W. A. A.-Q. I. Hamid, A. A. Abd-Aziz, S. Syed Muhamad, S. K. and Saari, N. (2014). "Preparation of bioactive peptides with high angiotensin converting enzyme inhibitory activity from winged bean (Psophocarpus tetragonolobus (L.) DC.) seed," Journal of Food Science and Technology, 51(12): 3658-3668.

[4] Sprent, J. I., Odee, D. W. and Dakra, F. D. (2010). African legume: A vital but underutilized resources. Journal of Experimental Botany, 61(5): 1257-1265.

[5] Vatanparast, M., Shetty, P., Chopra et al. (2016). “Transcriptome sequencing and marker development in winged bean (Psophocarpus tetragonolobus; Leguminosae),” Scientific Reports, vol. 6, no. 1, Article ID 29070.

[6] Massawea, F. J., Mayesa, S., Chenga, A., Chaia, H. H., Cleasbya, P., Symondsa, R. W. K., Hoab, W. K., Siisea, A., Wonga, Q. N., Kendabiec, P., Yanusaa, Y., Jamalluddina, N., Singha, A. and Azam-Alia, S. N. (2015). The potential for underutilized crops to improve food security in the face of climate change. Procedia Environmental Science, 29:140-141.

[7] Nyadanu, D. and Lower, S. (2014). Promoting competitiveness of neglected and underutilized crop species: comparative analysis of nutritional composition of indigenous and exotic leafy and fruit vegetables in Ghana. Genetic Resources Crop Evolution 61: 7.

[8] Gupta, P. K. (2006). Soil, Plant, Water and Fertilizer Analysis. Agrobios Agro House. Behind Nasraru Cinema Chopsail Road. Jodhpur (India). pp. 241.

[9] AOAC (Association of Official Analytical Chemists). (2005). Official Methods of Analysis of the Association of Analytical Chemists International, 18th ed. Gaithersburg, MD U.S.A Official method, 2005.08. 
[10] Chopra, S. L. and Kanwar, J. S. (1980). Analytical Agricultural Chemistry. Kalyani Publishers. New Delhi. pp. $337-346$.

[11] Wang, Y., Wisniewski, M., Meilan, R., Cui, M., Webb, R., Fuchigami, L. (2005). Overexpression of cytosolic superoxide dismutase in tomato confers tolerance to chilling and salt stress. Journal of American Society of Horticultural Science 130: 167-173.

[12] Adegunwa, M. Alamu, E. and Omitogun, L. (2011). "Effect of processing on the nutritional contents of yam and cocoyam tubers,” Journal of Applied Bioscience, vol. 46: 3086-3092.

[13] Makkar, H. P. S., Becker, K. (1997). Nutrients and antiquality factors in different morphological parts of the Moringa oleifera tree. Journal of Agricultural Science; 128:311-322. doi:10.1017/S0021859697004292. [CrossRef] [Google Scholar].

[14] Leyva, J. A. M., Artiga, M. P. H., M'endez, M. M. A. and P'er, J. J. Q. (1990). “Atomic absorption and UV-VIS absorption spectrophotometric determination of oxalate in urine by ligand exchange extraction,” Clinica Chimica Acta, vol. 195(1-2): 47-56.

[15] Gao, Y., Shang, C., Saghai Maroof, M. A., Biyashev, R. M., Grabau, E. A., Kwanyuen, P., Burton, J. W. and Buss, G. R. (2007). A modified colorimetric method for phytic acid analysis in soybean. Crop Science; 47:1797-1803. doi: 10.2135/cropsci2007.03.0122. [CrossRef] [Google Scholar].

[16] Khan, R. A. (2012). Protective effects of Sonchus asper (L.) Hill, (Asteraceae) against CCl induced oxidative stress in the thyroid tissue of rats. BMC Complement. Alternernative. Medicine12:181.

[17] Young, D. S. (2001). Effects of disease on clinical laboratory tests, 4th edition. AACC Press, Washington, DC, USA.

[18] Vadivel, V. and Janardhanan, K. (2001). "Nutritional and antinutritional attributes of the under-utilized legume, Cassia floribunda Cav.," Food Chemistry, 73 (2):209-215.

[19] James, C. S. (1995). Analytical Chemistry of Foods, Chapman \& Hall,New York, NY, USA, 1st edition.

[20] Pugalenthi, M., Vadivel, V., Gurumoorthi, P. and Janardhanan, K. (2004). Comparative nutritional evaluation of little known legumes, Tamarindus indica, Erythrina indica and Sesbania bispinosa, Tropical and Subtropical Agroecosystems, 4(3): 107-123.

[21] Marette, A. and Picard-Deland, E. (2014).Yogurt consumption and impact on health: focus on children and cardiometabolic risk. Americal ournal of Clinical Nutrition 99: 1243S-1247S

[22] AOAC Authors. (2006). Official methods of analysis Minerals Analysi-item 59. Association of Analytical Communities, Gaithersburg. MD. 17th edition. Reference data: Method 975.03B.

[23] Najafzadeh, H., Ghoreishi, S. M., Mohammadian, B., Rahimi, E. and Ganjealidarani, H. (2013). Serum biochemical and histopathological changes in kidney and liver in lambs after zinc oxide nanoparticles administration. Veterinary World. 6(8): 534-537. 